Abstract-Lost or derelict fishing gear can impair fisheries by contributing to the depletion of target species populations and can reduce nontarget fish and wildlife populations. We measured the density of derelict crab pot (DCPs) using side-scan sonar and examined bycatch associated with DCPs in nearshore waters (depths $\leq 4 \mathrm{~m}$ ) of 6 waterbodies important to the North Carolina blue crab fishery, the state's most valued commercial fishery. Extrapolated mean DCP density was $105 \mathrm{DCP} / \mathrm{km}^{2}$ of open water (range: 6-301). Densities of DCPs differed significantly among waterbodies but not among habitats (marsh creeks, estuarine edge $\leq 50 \mathrm{~m}$ from shore, and Atlantic Intracoastal Waterway margin). Extrapolated DCP densities were generally greater than those concurrently observed for actively fished crab pots within the $2011-\mathrm{km}^{2}$ cells sampled during 23 survey days between April and November 2010. Of the DCPs examined, $41 \%$ contained bycatch (unintentional catch) and $37 \%$ remained capable of trapping organisms. Bycatch was dominated by blue crab (Callinectes sapidus) and Florida stone crab (Menippe mercenaria) and included 5 diamondback terrapin (Malaclemys terrapin) and 1 clapper rail (Rallus crepitans). Based on monitoring of four $1-\mathrm{km}^{2}$ cells, annual DCP "recruitment" was 1.5 $\mathrm{DCP} / \mathrm{km}^{2}$ (1 SD). Reducing recruitment, persistence, and entrapment capability of DCPs would benefit the blue crab and Florida stone crab fisheries, as well as help conserve at-risk wildlife populations.

Manuscript submitted 21 January 2014. Manuscript accepted 2 July 2015.

Fish. Bull.: 113:378-390 (2015).

Online publication date: 21 July 2015. doi: 10.7755/FB.113.4.2

The views and opinions expressed or implied in this article are those of the author (or authors) and do not necessarily reflect the position of the National Marine Fisheries Service, NOAA.

\title{
Factors driving the density of derelict crab pots and their associated bycatch in North Carolina waters
}

\author{
Christine M. Voss ${ }^{1}$ \\ Joan A. Browder 2 \\ Andrew Wood ${ }^{3}$ \\ Adriane Michaelis ${ }^{3}$ \\ Email address for contact author: c.m.voss.unc@gmail.com \\ ${ }^{1}$ Institute of Marine Sciences \\ University of North Carolina \\ 3431 Arendell Street \\ Morehead City, North Carolina 28557 \\ 2 Southeast Fisheries Science Center \\ National Marine Fisheries Service, NOAA \\ 75 Virginia Beach Drive \\ Miami, Florida 33149 \\ ${ }^{3}$ Audubon North Carolina \\ 7741 Market Street \\ Unit D \\ Wilmington, North Carolina 28411
}

More than 1 million commercial crab pots are used annually in North Carolina, and an annual loss rate of $17 \%$ has been estimated by the North Carolina Division of Marine Fisheries $\left(\mathrm{NCDMF}^{1}\right)$. Estimated annual rates of crab pot losses were $30 \%$ in the lower York River, Virginia, for commercial and recreational pots combined (Havens et al., 2008) and $25 \%$ in the Gulf of Mexico for commercial pots only (Guillory et al. ${ }^{2}$ ). Because pots that are lost or aban-

${ }^{1}$ NCDMF (North Carolina Division of Marine Fisheries). 2008. Assess the effects of hurricanes on North Carolina's blue crab resource, 178 p. [Available from NCDMF, North Carolina Dep. Environ. Nat. Resour., 3441 Arendell St., Morehead City, NC 28557.]

2 Guillory, V., A. McMillen-Jackson, L. Hartman, H. Perry, T. Floyd, T. Wagner, and G. Graham. 2001. Blue crab derelict traps and trap removal programs. Gulf States Mar. Fish. Comm. Publ. 88, 13 p. [Available at website.] doned can continue to capture crabs, terrapins, fishes, and other wildlife for years, derelict crab pots (DCPs) pose a serious conservation problem in the coastal wetlands and shallow estuarine waters of North Carolina and elsewhere along the coasts of the U.S. Atlantic and Gulf of Mexico. North Carolina in recent years has ranked third or fourth among all states in annual commercial landings of hard-shell blue crab (NMFS, 20072014). The industry for hard-shelled blue crab (Callinectes sapidus) alone is the most highly valued commercial fishery in North Carolina (Burgess and Bianchi $^{3}$ ). Landings and value of

\footnotetext{
${ }^{3}$ Burgess, C. C., and A. J. Bianchi. 2004. An economic profile analysis of the commercial fishing industry of North Carolina including profiles for state-managed species, 123 p. Div. Mar. Fish., North Carolina Dep. Environ. Nat. Resour., Morehead City, NC. [Available at website.]
} 
peeler crab and soft-shell crab add to the value and are reported separately. In addition, a substantial recreational blue crab fishery exists in North Carolina. Crab pots are the principal fishing gear for all the hard-shell crab fisheries in North Carolina.

The unharvested "take" of blue crab and other fishery species in DCPs represents substantial mortality (Guillory, 1993; Guillory ${ }^{4}$ ) and is a drain on fishery catches and incomes. Substantial unintended incidental take, or bycatch, of wildlife also occurs in pots meant to capture blue crab (Havens et al., 2008; Morris et al., 2011). We extend the definition of bycatch to include blue crab and Florida stone crab (Menippe mercenaria), both live and dead, found in DCPs because the DCP catch is rendered unavailable to the fishery.

In a NCDMF ${ }^{1}$ study during $2002-2005$, the capture, mortality, and escapement rates of blue crab in DCPs in 4 regions (Alligator River, Pamlico River, Bogue Sound, and Middle Sound) of coastal North Carolina were estimated at an average yearly catch of 40.4 individuals/DCP for legally marketable blue crab. In that study, the overall mortality for blue crab in DCPs was $45 \%$, and the estimated annual escapement of blue crab from DCPs was 55\%; estimated annual finfish mortality was 2.5 individuals/DCP. In Virginia, Havens et al. (2008) estimated that about 50 marketable blue crab are killed per DCP each year. Other fishery and nonfishery species have been found either in or entangled by DCPs (Havens et al., 2011; $\mathrm{NCDMF}^{1}$; Guillory et al. ${ }^{2}$ ). Both actively fished crab pots (AFCPs) and DCPs pose a significant threat of drowning to diamondback terrapin (Malaclemys terrapin), a coastal species of concern in the states of Connecticut, Delaware, Maryland, Massachusetts, New Jersey, New York, North Carolina, Rhode Island, and Virginia (Roosenburg et al., 1997; Grosse et al., 2009). Organisms that die in a DCP can attract additional organisms that can become bycatch until that DCP is no longer capable of retaining organisms (degrades) or is removed.

The demographics of DCPs are not yet known for North Carolina. One might assume that DCP abundance is related to the number of AFCPs used in each waterbody. Likewise, the number of years that DCPs continue to trap animals is unknown. Shively ${ }^{5}$ found that, depending upon salinity, the functional life expectancy of vinyl-coated pots was 2 years or more in Texas. The research of Havens et al. (2008) in Virginia indicates that lost crab pots trapped animals for more than 1 year in higher-salinity areas (annual mean salinity=20 ) and probably longer in lower-salinity areas (annual mean salinity=6), where pots were slower to

${ }^{4}$ Guillory, V. 2001. A review of incidental fishing mortalities of blue crabs. In Proceedings: blue crab mortality symposium. Gulf States Mar. Fish. Comm. Publ. 90; Lafayette, LA, 28-29 May 1999 (V. Guillory, H. Perry, and S. Vanderkooy (eds.), p. 28-41. [Available at website.]

${ }^{5}$ Shively, J. D. 1997. Degradability of natural materials used to attach escapement panels to blue crab traps in Texas, 18 p. [Available from Natl. Mar. Fish. Serv., Southeast Reg., 9721 Executive Center Dr., North, St. Petersburg, FL 22702.] degrade. The rate at which pots become incapacitated can be affected by their rate of decomposition, bioerosion, and engulfment through encrustation by sessile organisms. These processes are likely to differ with habitat because of variation in salinity, dissolved oxygen, temperature, and other factors.

The type of habitat where DCPs are most likely to occur is poorly understood. Storms and currents often redistribute DCPs (Bishop, 1983), not necessarily to places where crabbing has taken place. In North Carolina, Avissar (2006) found that crabbers relocated their crab pots shoreward into shallow-water areas and tidal marsh creeks to avoid damage to the pots from sea turtles attempting to remove the bait, and Grant ${ }^{6}$ noted that capture rates of diamondback terrapin decreased with distance from shore. In Maryland, Roosenburg et al. (1999) noted that juvenile and male diamondback terrapin were more frequently observed in nearshore shallow areas, where they are more likely to interact with DCPs. Information about DCP density, transport, deposition, and longevity is needed if the limited resources available for DCP removal efforts are to be used more effectively.

The objectives of this study were to quantify the density, distribution, and bycatch of DCPs in 6 selected waterbodies on the central and southern coast of North Carolina, from Core Sound south to Cape Fear River, within 3 habitat types typically fished by crabbers that use hard-shell crab pots, marsh creek, margin of the Atlantic Intracoastal Waterway (ICW), and estuarine edge (within $50 \mathrm{~m}$ of shoreline). We test whether the density of DCPs differs among these waterbodies and the habitats.

\section{Materials and methods}

\section{Study area and mapping procedure for stratified random sampling}

The geographical range of this study spanned from Core Sound south to Cape Fear River, an area that includes 14 of 29 North Carolina inshore waterbodies. The 6 waterbodies that we sampled accounted for, on average, $74 \%$ of fishery landings of hard-shell crab in crab pots and $61 \%$ of fishing trips for hard-shell crab during which crab pots were used in the area from Core Sound south to the South Carolina border (NCD$\mathrm{MF}^{7}$ ) from 2006 to 2008. The sampled waterbodies, listed from north to south, were Core Sound, Newport River, Bogue Sound, Topsail Sound, Masonboro Sound, and the lower $16 \mathrm{~km}$ of the Cape Fear River (Fig. 1).

\footnotetext{
${ }^{6}$ Grant, G. S. 1997. Impact of crab pot excluder devices on diamondback terrapin mortality in commercial crab catch, 9 p. Unpubl. report. Univ. North Carolina at Wilmington, Wilmington, NC.

${ }^{7}$ NCDMF (North Carolina Division of Marine Fisheries). 2009. Unpubl. data. [Hard crabs and other species reported in crab pot landings in 2006-2009.] NCDMF, Morehead City, NC 28557.
} 


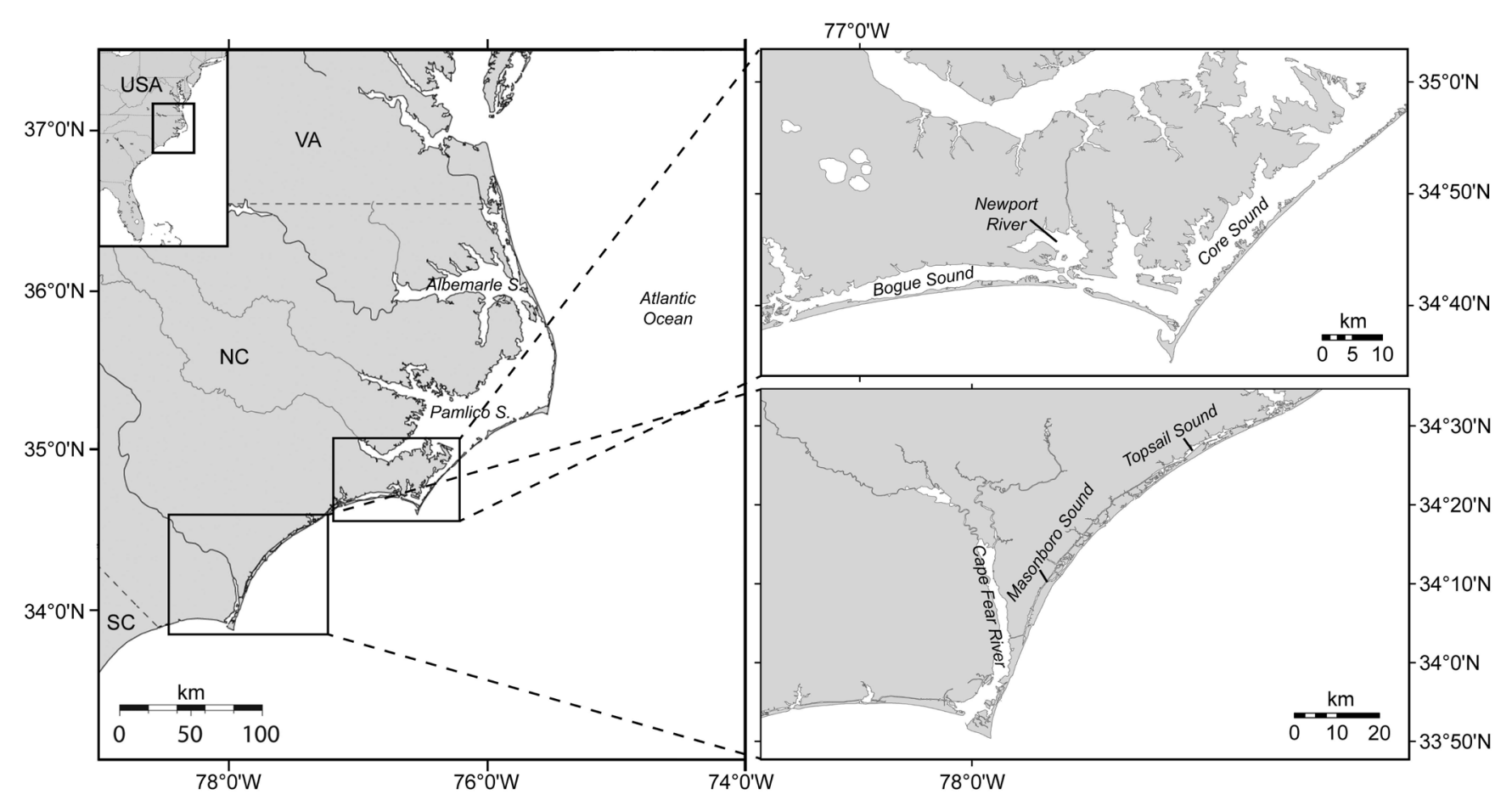

Figure 1

The locations of waterbodies sampled for assessing density of bycatch in derelict crab pots in North Carolina from April to November 2010: Bogue and Core sounds and Newport River (within the Central District of the North Carolina Division of Marine Fisheries) and Masonboro and Topsail sounds and Cape Fear River (within the Southern District).

We distinguished and sampled 3 habitat types in each waterbody: 1) marsh creeks; 2) estuarine edges (areas of open water within $50 \mathrm{~m}$ of the shoreline); and 3) areas adjacent to the ICW. Because one goal was to examine the interactions of diamondback terrapin with DCPs, we limited our surveys to nearshore waters with depths $\leq 4 \mathrm{~m}$, where diamondback terrapins and DCPs were most likely to co-occur. Given Avissar's (2006) observation that most blue crab fishermen now locate their pots near to shore to avoid sea turtle interference, our focus on the nearshore habitat probably provides good coverage of the area of activity for crab pot fishing.

With ArcMap, ${ }^{8}$ vers. 9.3.1 (Esri, Redlands, CA), we used readily available maps and shapefiles to classify areas as adjacent to the ICW or as estuarine edge; however, we had to create by hand a unique shapefile for marsh creek areas in each waterbody, digitizing these creeks with Google Earth software. A grid of $1-\mathrm{km}^{2}$ cells was placed over the habitat-classified map, and then each cell in our entire study area was assigned to one or more habitat types. The $1-\mathrm{km}^{2}$ grid was placed over our study area in the habitat-classified map with Google Earth software, which allowed

\footnotetext{
${ }^{8}$ Mention of trade names or commercial companies is for identification purposes only and does not imply endorsement by the National Marine Fisheries Service, NOAA.
}

us to eliminate inappropriate cells (i.e., estuarine edge cells with insufficient water surface area, and marsh creek cells where the entire natural shoreline was hardened) from the pool of possible cells. Approximately $20 \%$ open water was considered sufficient water surface area in most cases; very few marsh creek cells were as low as $10 \%$ open water. All sufficient cells had much more than the $24,000-\mathrm{m}^{2}$ area of water that we sampled within each cell. In addition, we eliminated cells known to be in an area included in the NCDMF program for removing and disposing of lost and abandoned crab pots.

A stratified random sampling design was used to select the cells to be sampled. A total of 1088 cells formed our sampling pool. Each cell was designated by habitat type within each waterbody, with the possibility that a given cell could represent more than one habitat type. Using ArcMap, we delineated the $1-\mathrm{km}^{2}$ cells, determined the latitude and longitude of cell centroids, and calculated the area of open water for each cell. We determined that our resources allowed us to survey approximately 200 cells overall, a count that could include some of the same cells twice (as separate samples because they represented 2 different habitat types). The number of cells to be sampled in each waterbody was determined by a weighting method for both the relative numbers of fishing trips with hard-shell crab pots (averaging $\mathrm{NCDMF}^{7}$ data for 2006-2008) and the 


\section{Table 1}

Distribution of sampling effort and raw abundance of derelict crab pots (DCPs) and actively fished crab pots (AFCPs) found within cells (each $1 \mathrm{~km}^{2}$ ) sampled in 2010 during a survey of marsh creek, estuarine edge, and adjacent Atlantic Intracoastal Waterway (ICW) habitats in Bogue, Core, Masonboro, and Topsail sounds and Cape Fear and Newport rivers in North Carolina. Abundance of DCPs is the number observed in the $24,000-\mathrm{m}^{2}$ areas surveyed in sampled cells, and abundance of AFCPs is the number observed in the entirety of the $1-\mathrm{km}^{2}$ cells. Note that the ICW does not traverse Core Sound and was not sampled in Cape Fear River because depths were $>4 \mathrm{~m}$.

\begin{tabular}{|c|c|c|c|c|c|c|c|c|c|c|c|c|}
\hline \multirow[b]{2}{*}{ Waterbody } & \multicolumn{3}{|c|}{ Number of cells sampled } & \multirow{2}{*}{$\begin{array}{c}\text { Total } \\
\text { cells } \\
\text { sampled }\end{array}$} & \multicolumn{3}{|c|}{ DCP abundance } & \multirow[b]{2}{*}{$\begin{array}{l}\text { Total } \\
\text { DCPs }\end{array}$} & \multicolumn{3}{|c|}{ AFCP abundance } & \multirow[b]{2}{*}{$\begin{array}{r}\text { Total } \\
\text { AFCP }\end{array}$} \\
\hline & $\begin{array}{l}\text { Marsh } \\
\text { creek }\end{array}$ & $\begin{array}{l}\text { Estuarine } \\
\text { edge }\end{array}$ & $\begin{array}{l}\text { Adjacent } \\
\text { ICW }\end{array}$ & & $\begin{array}{l}\text { Marsh } \\
\text { creek }\end{array}$ & $\begin{array}{l}\text { Estuarine } \\
\text { edge }\end{array}$ & $\begin{array}{l}\text { Adjacent } \\
\text { ICW }\end{array}$ & & $\begin{array}{l}\text { Marsh } \\
\text { creek }\end{array}$ & $\begin{array}{l}\text { Estuarine } \\
\text { edge }\end{array}$ & $\begin{array}{l}\text { Adjacent } \\
\text { ICW }\end{array}$ & \\
\hline Bogue Sound & 8 & 8 & 8 & 24 & 8 & 1 & 1 & 10 & 58 & 106 & 94 & 258 \\
\hline Cape Fear River & 30 & 30 & - & 60 & 14 & 13 & - & 27 & 48 & 51 & - & 99 \\
\hline Core Sound & 30 & 30 & - & 60 & 9 & 8 & - & 17 & 369 & 219 & - & 588 \\
\hline Masonboro Sound & 9 & 9 & 9 & 27 & 20 & 19 & 4 & 43 & 20 & 53 & 55 & 128 \\
\hline Newport River & 5 & 5 & 5 & 15 & 0 & 1 & 0 & 1 & 43 & 24 & 20 & 87 \\
\hline Topsail Sound & 5 & 5 & 5 & 15 & 1 & 3 & 4 & 8 & 19 & 14 & 18 & 51 \\
\hline Totals & 87 & 87 & 27 & 201 & 52 & 45 & 9 & 106 & 557 & 467 & 187 & 1211 \\
\hline
\end{tabular}

relative combined area of marsh creek, estuarine edge, and ICW-margin habitats within each waterbody.

For each waterbody, we multiplied the proportion of total trips by the proportion of total area of the 3 habitat types combined. Sampling effort, or the number of cells to be sampled, was then allocated to waterbodies in proportion to the product of the 2 proportions. Each of 1088 cells was categorized by waterbody and habitat type and a random number generator was used to rank the priority of the cells for sampling. We determined that a 201-cell sampling design allowed us to balance effort among habitat types within waterbodies. To distribute the $2011-\mathrm{km}^{2}$ cells to be sampled across the 6 waterbodies, the number of cells assigned to each waterbody were divided equally among the 3 habitat types (Table 1), with the exceptions of the 2 waterbodies that lacked appropriate ICW habitat: Core Sound, which the ICW does not traverse, and the lower Cape Fear River, where the ICW is a major shipping channel with all depths $>4 \mathrm{~m}$. In those 2 waterbodies, the number of cells to be sampled was divided evenly between the habitat types of marsh creek and estuarine edge (Table 1).

\section{Field sampling}

Sampling was conducted within 99 cells over 11 field days, between 28 April and 3 June 2010 in the Core Sound, Newport River, and Bogue Sound (within the Central District of the NCDMF) and within 102 cells over 12 field days, between 10 May and 10 August and on 11 November 2010 in Topsail Sound, Masonboro Sound, and Cape Fear River (within the Southern District of the NCDMF) (Fig. 1). Of the 201 cells sampled, 23 cells that were randomly selected to represent 2 different habitat types were sampled twice, accounting for 46 of the 201 samples. A team from the University of North Carolina at Chapel Hill Institute of Marine Sciences conducted surveys in the Central District, and a team from Audubon North Carolina conducted surveys in the Southern District. Two scientists, one from each sampling team, met to discuss details of sampling protocols, and subsequently practiced and standardized techniques during a day on the water dedicated to standardize methods before sampling was conducted.

The latitude and longitude of each target cell's centroid were used to locate cells in the field with a handheld GPS (GPSMAP $76 \mathrm{Cx}$ or $60 \mathrm{CSx}$, Garmin International, Inc., Olathe, KS). GPS also was used to determine the cell boundaries in relation to each centroid. This method of field demarcation enabled the definition of each $1-\mathrm{km}^{2}$ cell, within which both DCPs and AFCPs were counted. DCPs, which lacked surface buoys, were detected with the use of side-scan sonar, and AFCPs, which had one floating buoy per pot, were detected visually.

Within each sampled $1-\mathrm{km}^{2}$ cell, 4 separate transects (30 m wide by $200 \mathrm{~m}$ long) were haphazardly chosen and surveyed by boat with no overlap of sampling area (for a total sampled area of $24,000 \mathrm{~m}^{2}$ ) to detect DCPs with Humminbird 1197c high definition side imaging sonar (Johnson Outdoors Marine Electronics, Inc., Racine, WI), combined with a GPS. Transect distances were verified by both one of the handheld GPSMAPs and the Humminbird sonar. Each team surveyed transects in either a linear or a curved pattern that was tailored to the shape of estuarine contours within a given cell. In some cases, shallow water allowed DCPs to be located visually. During the same survey, all AF$\mathrm{CPs}$, with their required float visible on the water's surface, were counted visually, within each $1-\mathrm{km}^{2}$ cell that was demarcated by using both the handheld and Humminbird GPSs. 


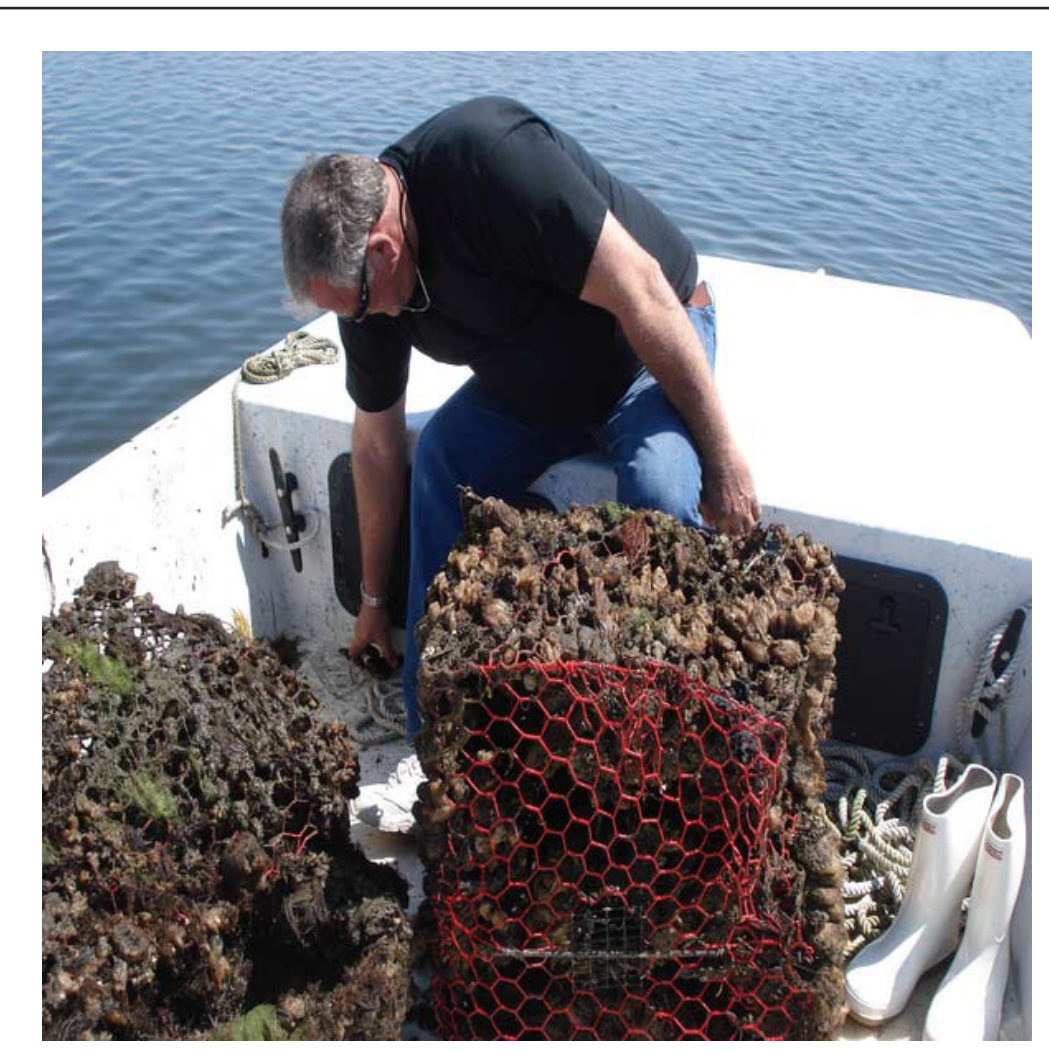

Figure 2

Photograph of derelict crab pots retrieved from Bogue Sound and the Newport River, North Carolina, in May 2010: (left) a pot in poor condition (rank of 9), with a partial wall collapse that allowed unrestricted movement of organisms, and (right) a pot in fair condition (rank of 5), well fouled yet structurally intact and capable of trapping organisms.

water (soak time), and the identification and percent cover of fouling organisms on each DCP were recorded. Estimates of DCP soak times were determined by the same researcher in each region who had participated in the technique-standardization trip, on the basis of the degree of fouling and bivalve recruitment that had accumulated on pots. Although soak time was a subjective measure, each of the researchers who estimated soak times had $>40$ years of experience working in estuaries to guide their estimates. These estimates were consistent with the descriptions and images of crab pots after known soak times in North Carolina high-salinity (annual mean salinity=30) estuaries that were provided in the $\mathrm{NCDMF}^{1}$ report. In general, DCPs that received a condition score of $\leq 4$ had estimated soak times of $\leq 1$ year, and pots that had a condition rank $\geq 9$ had estimated soak times of $\geq 2$ years.

Environmental data (temperature, salinity, and dissolved oxygen) for each cell were recorded with a YSI ProPlus water quality meter (YSI, Inc., Yellow Springs, OH), and, for each DCP found in a cell, its distance from shore was recorded. Aquatic organisms found in bycatch or living on recovered DCPs were identified (according to Gosner, 1971, Robins et al., 1986; Ruppert and Fox, 1988; FishBase, vers. 2/2010, available at website) to the lowest

Crab pots were distinguished from other benthic objects and debris in images from the side-scan sonar on the basis of their square shape, dimensions, and acoustic shadow distal to the nadir (Havens et al., 2008; Morison and Murphy, 2009). The crab pots typically used in both the commercial and recreational hard-shell blue crab fishery are $60 \mathrm{~cm}$ in length, $60 \mathrm{~cm}$ in width, and $50 \mathrm{~cm}$ in height, and they are constructed of vinyl-coated wire, with a center chamber in which bait is secured (Fig. 2). Metal rebar is often wired to a pot's bottom surface to ensure that it is properly oriented as it settles upon the estuarine floor after deployment. When a DCP was discovered, the time and GPS coordinates were recorded. A 30-m waterman's rope (a rope to which bent nails are attached in increments of $30 \mathrm{~cm}$ ) or a grapple was used to retrieve DCPs and haul them aboard the boat for inspection and to record bycatch metrics; in some cases, pots were in such poor condition that they were ripped apart upon haul-out and only pot parts were recovered.

Data on DCP construction (wire type and pot design) and condition (functionality ranking, from 1 to 10, with 1 for structurally sound and 10 for totally dilapidated; Table 2), an estimate of each DCP's time in possible taxonomic level, classified as living or dead, counted, measured, and released. The total length of fishes and the carapace width $(\mathrm{CW})$, point to point (distance between posterior lateral spines of the carapace) of crabs were used as standard measures of organism size. For blue crab, adults were distinguished from juveniles by having a $\mathrm{CW} \geq 5.6 \mathrm{~cm} \mathrm{CW}$, the smallest size considered mature for a female crab with a full apron $\left(\mathrm{NCDMF}^{9}\right)$; legal market size for this species in North Carolina is $\geq 12.5 \mathrm{~cm} \mathrm{CW}$ for males and $\geq 17 \mathrm{~cm} \mathrm{CW}$ for females $\left(\mathrm{NCDMF}^{9}\right)$. For Florida stone crab, adults were distinguished from juveniles by having a $\mathrm{CW} \geq 3.0 \mathrm{~cm}$; coloration patterns did not differ with age (Lindberg and Marshall $\left.{ }^{10}\right)$.

${ }^{9}$ NCDMF (North Carolina Division of Marine Fisheries). 2004. North Carolina Fishery Management Plan: Blue Crab, 133 p. +app. Div. Mar. Fish., North Carolina Dep. Environ. Nat. Resour., Morehead City, NC. [Available at website.] ${ }^{10}$ Lindberg, W. J., and M. J. Marshall. 1984. Species profiles: life histories and environmental requirements of coastal fishes and invertebrates (south Florida) stone crab. U.S. Fish Wildl. Serv. FWS/OBS-82/11.21 and U.S. Army Corps Eng. TR EL-82-4, 17 p. [Available at website.] 


\begin{tabular}{|cl|}
\hline & \multicolumn{1}{c|}{ Table 2} \\
Condition of derelict crab pots was ranked on a scale of $1-10$. This table provides the de- \\
scriptors used to rank the condition of pots. \\
\hline Condition rank & Descriptors \\
\hline 1 & Structural integrity of pot sound; some rust or discoloration may be seen \\
2 & Pot retains original shape but shows wear and abrasion \\
3 & Pot structure intact, with obvious flaws in wall or floor \\
4 & Pot likely misshapen; walls or floor beginning to degrade \\
6 & Observable decay of structure, with pits in walls or floor \\
7 & Small voids in walls or floor \\
8 & Walls or floor are clearly deteriorated; partial collapse likely \\
9 & Holes $\geq 10$ cm in walls or floor \\
10 & Structural integrity of pot has failed; walls or floor well decayed \\
& Total dilapidation; parts of walls or floor well disintegrated \\
\hline
\end{tabular}

Bivalve size was measured by the perpendicular axes of height, from umbo to distal tip, and length, the longest axis from anterior to posterior ends. All size measurements were recorded to the closest $1 \mathrm{~mm}$. After all data were collected and all animals were released from a pot, it was flattened and taken for proper disposal.

To estimate the recruitment rate of DCPs in areas where crabbing commonly occurs in North Carolina, we carefully removed all DCPs from four $1-\mathrm{km}^{2}$ cells, one cell each in Bogue Sound (near Archer's Creek) and in the eastern area of Newport River in the Central District and in Topsail Sound (behind Figure Eight Island), and Masonboro Sound (behind Masonboro Island) in the Southern District in spring 2010. These 4 cells were intensively resurveyed for newly recruited DCPs after 1 year (52 and 51 weeks later in the Central and Southern Districts, respectively). We worked with the North Carolina Marine Patrol of the NCDMF to ensure that the 4 areas used for this study component were $>5$ $\mathrm{km}$ from state waters included in the NCDMF program for removing and disposing of lost and abandoned crab pots (Anthony and Knudsen ${ }^{11}$ ).

\section{Data analyses}

Data on DCPs, AFCPs, coordinates for surveyed transect area, and DCP bycatch and attached organisms for all 6 waterbodies were combined. SYSTAT, vers. 13.00.05 (Systat Software, Inc., San Jose, CA) and JMP, vers. 8.0 (SAS Institute, Inc., Cary, NC) software packages were used for statistical analyses. Because the area of some sampled $1-\mathrm{km}^{2}$ cells included land, we used a conversion factor to standardize the data to the proportion of open water in each cell as computed by ArcMap. Here, the number of DCPs found in each $24,000-\mathrm{m}^{2}$ area or ACFPs in a $1-\mathrm{km}^{2}$ cell was multi-

\footnotetext{
11Anthony, S., and H. Knudsen. 2010. Personal commun. Marine Patrol, Div. Mar. Fish., North Carolina Dep. Environ. Nat. Resour., Morehead City, NC 28557.
}

plied by the proportion-open-water conversion factor, with DCPs also multiplied by 41.667 , to calculate the density of DCPs and AFCPs as the number of pots per square kilometer of open water. Density values for both DCPs $(\lambda:-0.6)$ and AFCPs $(\lambda$ : -0.2$)$ were Box-Cox transformed to preclude significant departure from homogeneity of variance as confirmed afterward by either O'Brien's or Bartlett's tests $(\alpha=0.05)$.

Two-way analyses of variance (ANOVAs) were conducted on data to test whether waterbody or habitat type were significant factors explaining differences in DCP and AFCP density and to test whether interactions between habitat type and waterbody existed. Tukey's honestly significant difference tests were conducted post hoc to examine differences in DCP and AFCP densities among the waterbodies and habitats we sampled. Because of the lack of a linear relationship between DCPs and AFCPs, analysis of covariance was unwarranted. Two-way ANOVAs were used to compare bycatch abundance of blue and Florida stone crabs by waterbody and habitat type, as well as to determine whether an interaction between factors existed. The bycatch abundance data for both blue and Florida stone crabs were Box-Cox transformed to meet normality criteria before ANOVAs. To investigate the effects of including cells that represented more than one habitat type, results from 2 -way ANOVAs that included all $(n=201)$ cells were compared with 2-way ANOVAs that excluded the cells that served for 2 habitat types $(n=155)$. In cases where the arithmetic mean is given, the standard deviation (SD) is also presented in parentheses.

\section{Results}

\section{Density of crab pots}

The 201 cells within the selected 6 waterbodies in North Carolina were scanned with a side-scan sonar and 106 DCPs were detected (Table 1). By extrapolat- 
ing the values of DCP abundance found in the 24,000$\mathrm{m}^{2}$ areas surveyed within cells to estimate the number of DCPs in each square kilometer of open water, we computed a mean of $105 \mathrm{DCP} / \mathrm{km}^{2}$ in open water in the 6 waterbodies that produced $61-74 \%$ of the commercial hard-shell crab catch in 2006-2008 in North Carolina from Core Sound south to the South Carolina border. Extrapolated DCP densities in open water for each waterbody ranged from $6 \mathrm{DCP} / \mathrm{km}^{2}$ in the Newport River to $301 \mathrm{DCP} / \mathrm{km}^{2}$ in Topsail Sound (Fig. 3). Two-way ANOVA revealed that estimates of DCP densities differed significantly by waterbody $\left(F_{(3)}=4.18, P=0.007\right)$ but not by habitat type $\left(F_{(1)}=0.043, P=0.84\right)$, and revealed no interaction between these factors $\left(F_{(8)}=0.448\right.$, $P=0.89$ ) (Fig. 3). Likewise, we did not detect differences in DCP density $(P \geq 0.37)$ by habitat type when analyzed within each waterbody.

During our sampling of the $2011-\mathrm{km}^{2}$ cells over 23 survey days from April to November 2010, 1211 AFCPs were observed concurrently with DCPs (Table 1), yielding a mean AFCP density of $19 \mathrm{AFCP} / \mathrm{km}^{2}$ in open water. The densities of AFCPs in open water ranged from $8 \mathrm{AFCP} / \mathrm{km}^{2}$ in Cape Fear River to $32 \mathrm{AFCP} /$ $\mathrm{km}^{2}$ in Bogue Sound (Fig. 3). Using 2-way ANOVA, we did not detect differences in the densities of AFCPs by waterbody $\left(F_{(3)}=0.232, P=0.87\right)$ or by habitat type $\left(F_{(1)}=0.627, P=0.26\right)$, and any interaction between these factors $\left(F_{(8)}=0.66, P=0.73\right)$ (Fig. 3). As with the DCPs, the density of AFCPs did not differ significantly $(P \geq 0.29)$ by habitat type when analyzed within each waterbody.

Of the 201 cells sampled, 23 cells represented 2 different habitat types (accounting for 46 of 201 samples because they were sampled twice) and 155 cells represented only 1 habitat type. A 2-way ANOVA of the 155 cells that represented only 1 habitat type yielded results similar to those of the analyses that included all 201 cells. For the subset of 155 cells, DCP densities differed significantly by waterbody $\left(F_{(3)}=3.56\right.$, $P=0.012)$ but not by habitat type $\left(F_{(1)}=0.18, P=0.89\right)$, and there was no interaction between these factors $\left(F_{(8)}=1.06, P=0.39\right)$. In contrast, for this subset of cells, we detected no differences in ACFP densities by waterbody $\left(F_{(3)}=0.50, P=0.66\right)$ or by habitat type, $\left(F_{(1)}=0.77\right.$, $P=0.38)$ and no interaction $\left(F_{(8)}=0.72, P=0.67\right)$ between these factors. Additionally, we detected no differences in DCP density or AFCP density among habitat types within waterbodies.

\section{Characterization of derelict crab pots}

Of the 106 DCPs found during field surveys, 92 (86.8\%) were retrieved. These $92 \mathrm{DCPs}$ were in the water for an estimated mean of 2.09 years (SD 1.30). For retrieved DCPs, condition was ranked on a scale ranging from 1 to 10 with a mean value of 6.8 (SD 2.74) (see ranking system in Table 2; see Fig. 2 for examples of DCPs in poor [rank value of 9] and fair [5] condition). Of these pots, 34 DCPs (37\%) were functional and capable of trapping organisms (Fig. 2), and these DCPs had no markings or floats that would make visual detection possible from the surface. About $51 \%$ or 47 of the 92 DCPs were buried in estuarine sediments and had a mean burial depth of $7.87 \mathrm{~cm}$ (SD 10.57) measured from pot bottom. With organisms, such as macroalgae, soft corals, sponges, tunicates, bivalves, and bryozoans growing on their walls, 27 DCPs supported fouling communities.

\section{Bycatch of derelict crab pots}

Of the 92 DCPs retrieved for analysis of bycatch (Table 3), 38 DCPs (41.3\%) contained bycatch organisms. A total of 45 taxa were identified in or on these pots. Of these 45 identified taxa, 18 species (Table 4), represented by 531 individuals, were bycatch, inhibited from leaving the DCP. The most abundant bycatch species of fisheries interest were blue crab and Florida stone crab; sheepshead (Archosargus probatocephalus) and black sea bass (Centropristis striata) were also among DCP bycatch (Fig. 4).

Of the 25 blue crab found as bycatch, all were considered adults $(\mathrm{CW} \geq 5.6 \mathrm{~cm}$ [point to point], the minimum size of mature females as defined in $\mathrm{NCDMF}^{9}$; females also had to exhibit a rounded abdominal apron), 10 were dead, and 11 were of legal market size (males $\geq 12.7 \mathrm{~cm} \mathrm{CW}$ and females $\left.\geq 17 \mathrm{~cm} \mathrm{CW}_{\text {[NCDMF}}{ }^{9}\right]$ ); for 3 of these 25 crab, size was estimated allometrically from claw size. Of the 69 Florida stone crab found as bycatch, only 1 was dead and $23(33 \%)$ were juveniles (CW: $1.25-3.00 \mathrm{~cm}$; Lindberg and Marshall ${ }^{10}$ ).

Blue crab bycatch abundance did not differ significantly among waterbodies $\left(F_{(2)}=1.50, P=0.23\right)$ or among habitat types $\left(F_{(1)}=0.06, P=0.80\right)$ (Fig. 4$)$. The interaction between these factors was significant $\left(F_{(6)}=2.66\right.$, $P=0.02$ ) as a consequence of relatively high numbers of blue crab found in estuarine edge habitat in Core Sound and in marsh creek habitat in the Cape Fear River. The relative proportions of available estuarine edge and marsh creek habitats in these respective waterbodies did not explain patterns in abundances of blue crab in DCPs. Bycatch abundance of Florida stone crab did not differ significantly among waterbodies $\left(F_{(2)}=0.37, P=0.70\right)$ or among habitat types $\left(F_{(1)}=2.74\right.$, $P=0.10$ ) (Fig. 4). The interaction between these factors was not significant $\left(F_{(6)}=2.16, P=0.056\right)$, yet it was influenced by the relatively high abundance of Florida stone crab found in estuarine edge habitat in Core Sound, which was dominated by juveniles, and in marsh creek habitat in Bogue Sound.

The most important bycatch species of conservation interest were 5 diamondback terrapin and 1 clapper rail (Rallus crepitans). Other abundant nonfishery species were mud crabs (family Xanthidae), portly spider crab (Libinia emarginata), blennies (suborder Blennioidei), pinfish (Lagodon rhomboides), and oyster toadfish (Opsanus tau). Eastern oyster (Crassostrea virginica) had recruited to 16 of the 92 pots retrieved, and recruitment of northern quahog (Mercenaria mercenaria) was also substantial. Several species of bryozoans (phy- 

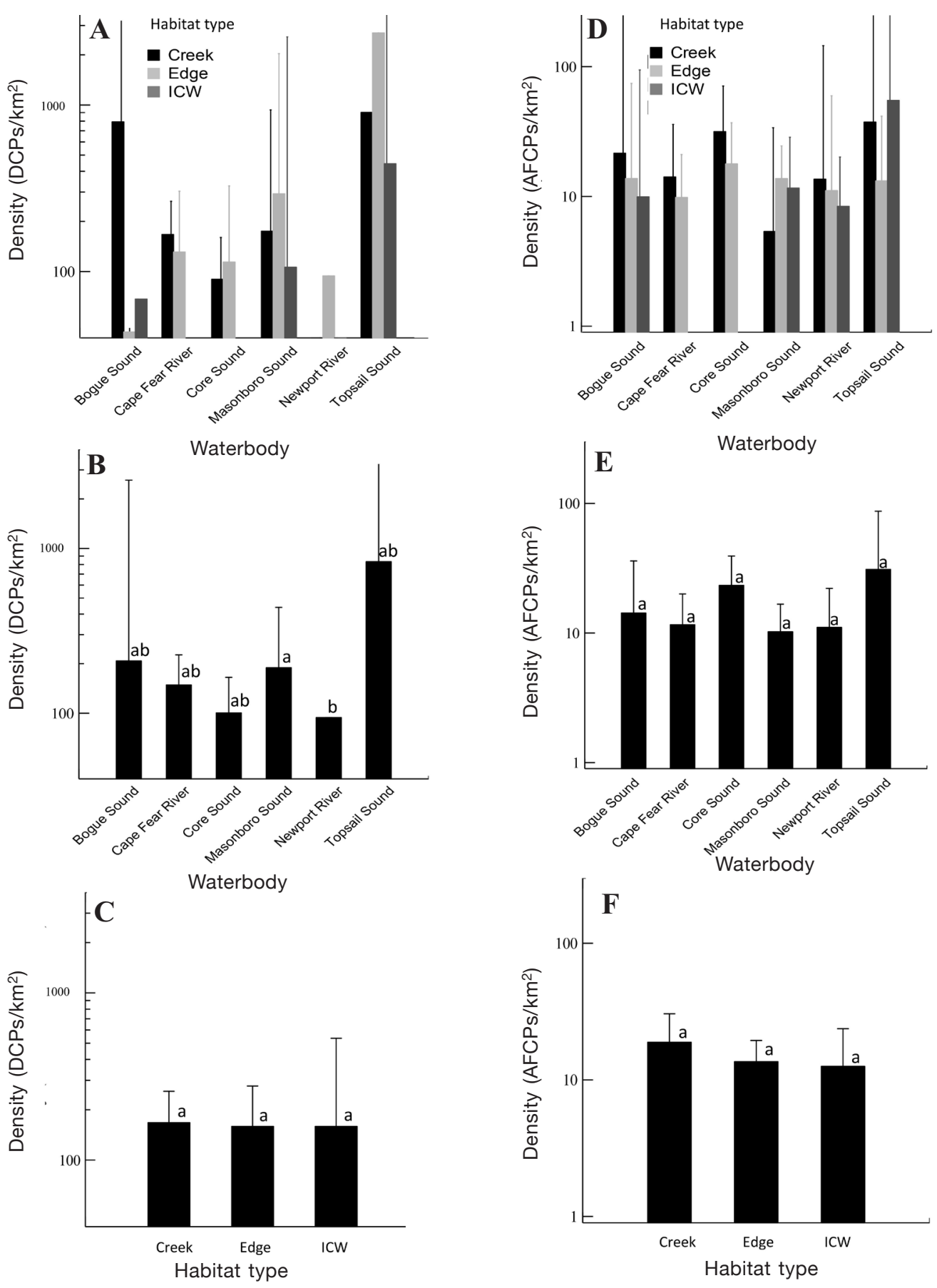

Figure 3

Mean densities of derelict crab pots (DCPs), extrapolated to the number of DCPs per square kilometer of open water (A) by habitat type (marsh creek, estuarine edge, and areas adjacent to the Atlantic Intracoastal Waterway [ICW]) and by each of 6 waterbodies in North Carolina (Bogue, Core, Masonboro, and Topsail sounds and Cape Fear and Newport rivers), (B) by waterbody, and (C) by habitat type, and mean densities of actively fished crab pots (AFCPs) extrapolated to number of AFCPs per square kilometer of open water of open water $(\mathbf{E})$ by habitat type and by each of the 6 waterbodies, (F) by waterbody, and (F) by habitat type, as observed by side-scan sonar or visually, from April to November 2010. Note that the logarithmic scales used on the $y$-axes differ between graphs for DCP densities and graphs for AFCP densities. Levels not sharing the same letter differ significantly $(P \leq 0.05)$ in Tukey's honestly significant difference post-hoc comparison of least square means of Box-Cox transformed data (panels B, C, E, and F). Error bars indicate standard errors. 
Table 3

Abundance of derelict crab pots (DCPs) retrieved for collection of bycatch data during surveys of marsh creek, estuarine edge, and adjacent Atlantic Intracoastal Waterway (ICW) habitats in Bogue, Core, Masonboro, and Topsail Sounds and the Cape Fear and Newport rivers in North Carolina from April to November 2010. Note that the ICW does not traverse Core Sound and was not sampled in Cape Fear River because depths were $>4 \mathrm{~m}$.

\begin{tabular}{lcccc}
\hline & \multicolumn{3}{c}{ Habitat type } & $\begin{array}{c}\text { Total number of } \\
\text { DCPs retrieved }\end{array}$ \\
\cline { 2 - 4 } Waterbody & Marsh creek & Estuarine edge & Adjacent ICW & 1 \\
Bogue Sound & 4 & 1 & - & 6 \\
Cape Fear River & 13 & 9 & - & 11 \\
Core Sound & 5 & 6 & 4 & 43 \\
Masonboro Sound & 20 & 19 & 0 & 9 \\
Newport River & 0 & 1 & 4 & 92 \\
Topsail Sound & 1 & 4 & 9 & \\
$\quad$ Total DCPs retrieved & 43 & 40 & & \\
\end{tabular}

lum Bryozoa), tunicates (subphylum Urochordata), and estuarine algae also were growing on retrieved DCPs.

\section{Recruitment of derelict crab pots}

Surveys of DCPs 1 year after meticulous removal of DCPs present in 4 cells (each $1 \mathrm{~km}^{2}$, all $100 \%$ open water) resulted in the finding of 6 new pots: 1 in each of 3 cleared cells (Bogue and Masonboro sounds and
Newport River) and 3 in the cleared cell near Figure Eight Island in Topsail Sound. On the basis of these recoveries, we estimated an annual DCP recruitment rate of $1.0 \mathrm{DCP} / \mathrm{km}^{2}$ in Bogue and Masonboro sounds and Newport River and of $3 \mathrm{DCP} / \mathrm{km}^{2}$ in Topsail Sound. From this survey of only four $1-\mathrm{km}^{2}$ cells, we found an overall annual mean DCP recruitment rate of $1.5 \mathrm{DCPs} /$ $\mathrm{km}^{2}$ (SD 1.0), yielding lower and upper 95\% confidence levels of -0.09 and $3.09 \mathrm{DCPs} / \mathrm{km}^{2}$, respectively. Of the

\section{Table 4}

Faunal bycatch (trapped and unrestricted) species and number caught in 92 derelict crab pots retrieved between April and November 2010 from Bogue, Core, Masonboro, and Topsail Sounds and the Cape Fear and Newport rivers in North Carolina. Trapped organisms were those that were confined, and escape was unlikely, once they entered pots. Unrestricted organisms were those that were free to pass through pot walls yet were captured when the pots were retrieved.

\begin{tabular}{llrr}
\hline Common name & \multicolumn{1}{c}{ Taxonomic name } & $\begin{array}{c}\text { Number of } \\
\text { organisms trapped }\end{array}$ & $\begin{array}{c}\text { Number of } \\
\text { unrestricted organisms }\end{array}$ \\
\hline Blue crab & Callinectes sapidus & 25 & 0 \\
Florida stone crab & Menippe mercenaria & 46 & 23 \\
Mud crabs & Xanthidae. & 0 & 267 \\
Spider crabs & Majidae. & 15 & 0 \\
Oyster toadfish & Opsanus tau & 40 & 0 \\
Sheepshead & Archosargus probatocephalus & 4 & 0 \\
Blennies. & Suborder Blennioidei & 0 & 47 \\
Black sea bass & Centropristis striata & 1 & 0 \\
Pinfish & Lagodon rhomboides & 1 & 0 \\
Snapping shrimps & Alpheoidea & 0 & 27 \\
Banded tulip & Fasciolaria lilium & 0 & 1 \\
Polychaetes & Polychaeta & 0 & 4 \\
Brittle star & Ophiuroidea & 0 & 20 \\
Anemone & Anemone & 0 & 1 \\
Clapper rail & Rallus crepitans & 1 & 0 \\
Diamondback terrapin & Malaclemys terrapin & 5 & 0 \\
Hermit crabs & Paguroidea & 0 & 2 \\
Purple sea urchin & Strongylocentrotus purpuratus & 0 & 1 \\
& & & \\
\end{tabular}




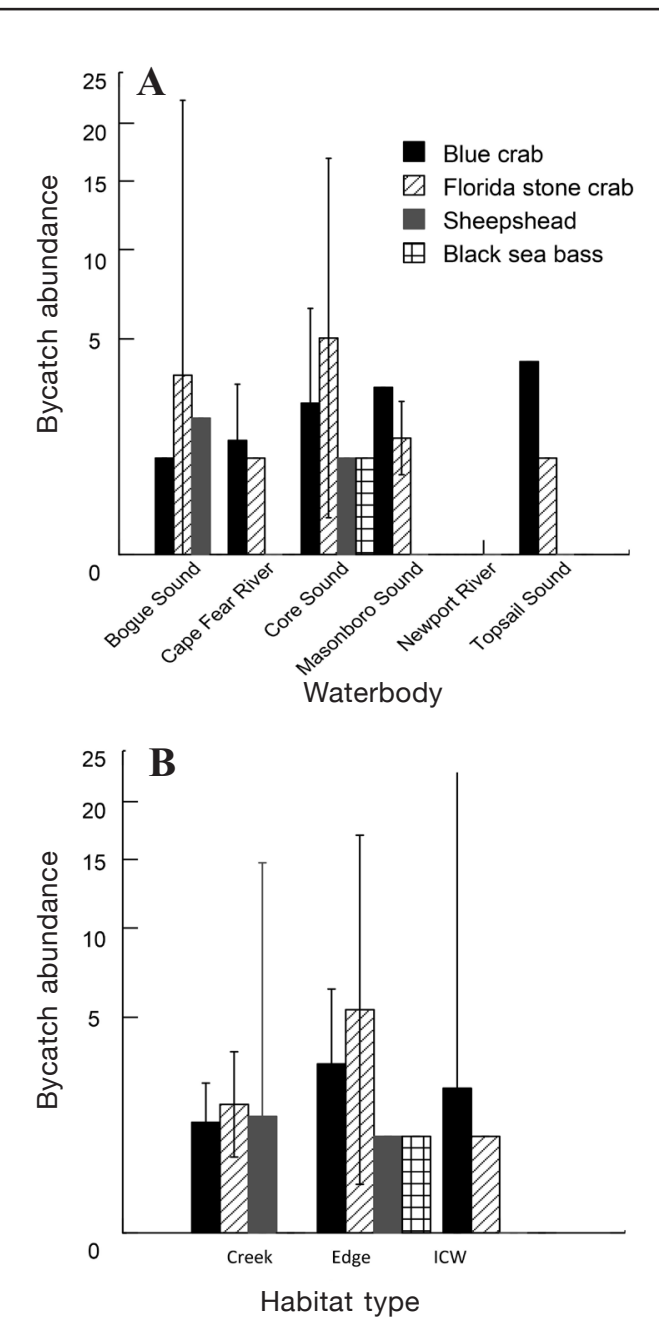

Figure 4

Abundance of 4 fishery species per $\mathrm{km}^{2}-$ the blue crab (Callinectes sapidus), Florida stone crab (Menippe mercenaria), sheepshead (Archosargus probatocephalus), and black sea bass (Centropristis striata)found among the bycatch of derelict crab pots (A) by waterbody and (B) by habitat type from April to November 2010 in 6 waterbodies (Bogue, Core, Masonboro, and Topsail sounds and Cape Fear and Newport rivers) of North Carolina.

6 retrieved DCPs, 2 were estimated to have been in the water for at least 2 years, on the basis of degree of fouling and size of attached eastern oysters. Three other introduced DCPs, each estimated to have been in the water for 1-1.5 years, were heavily fouled with algae and tunicates and were still capable of capturing bycatch. Live adult blue crab (5), Florida stone crab (8), and an oyster toadfish (1) were found in the 6 recovered DCPs, but they were not included in our bycatch database. One DCP was thought to have become der- elict within a few months of retrieval because its rebar was still intact.

\section{Discussion}

The occurrence of DCPs is a serious problem throughout North Carolina and in other states where the blue crab fishery that uses hard-shell crab pots contributes to the local heritage and economy. We were able to produce quantitative estimates of DCP density and abundance and of bycatch by waterbody and habitat in North Carolina. Our results document the magnitude of the problem and may help focus future cleanout efforts. This study shows that DCPs are introduced into areas not necessarily associated with crabbing activity because pots were probably transported by tides and storm currents. Further, a previously unrecognized source of mortality for fishery species and other wildlife-stacked pots stored on the marsh-was observed.

Derelict crab pots were abundant in 5 of the 6 waterbodies (Table 1) and were present in each of the 3 types of habitat surveyed (Table 1; Fig. 3), despite current crab pot regulations, management efforts to limit pot loss or abandonment, and programs to remove derelict gear. Lack of a significant difference in DCP density among habitat types may have been a result of the ecological similarity of the 3 habitats examined. All were situated in shallow water, they were adjacent to one another, and each was a likely focus of crabbing effort. Crabbers traditionally set lines of pots along the shallow edge of deeper water areas (such as channels) or in areas adjacent to salt marshes. Avissar (2006) found that crabbers moved their pots into shallower waters at the estuarine edge or toward the heads of marsh creeks to avoid pot damage caused by sea turtles seeking the enclosed bait. Hence, we expected to find higher DCP densities in marsh creek or estuarine edge habitats. Of all observed DCPs, 50\% were discovered in marsh creek habitat; however, this finding could result from lower sampling effort overall in ICW habitat or from the lack of appropriate ICW habitat in 2 of the studied waterbodies (Table 1 ).

We sampled with replacement for a selection of cells to represent each habitat type within each waterbody. This procedure resulted in 23 randomly selected cells being surveyed as 2 different habitat types, effectively duplicating results in 46 of the 201 sampled cells and possibly hindering our ability to detect differences in DCP density among habitat types. However, analysis of the subset of 155 single-habitat cells yielded the same patterns found in the analysis of the complete 201-cell data set, with significant differences in DCP densities found among the 6 waterbodies but not among the 3 habitat types and with no differences in AFCP densities detected among these factors.

Found in $46 \%$ of the 201 sampled cells, AFCPs were much more widely distributed than DCPs, which were found in only $9 \%$ of the sampled cells. This difference may have resulted from the 11-fold higher number of 
observed AFCPs than of observed DCPs, 1211 versus 106 (Table 1) and from the 41 times greater survey area over which AFCPs were counted, $1 \mathrm{~km}^{2}$ versus $24,000 \mathrm{~m}^{2}$ (or $0.024 \mathrm{~km}^{2}$ ).

The results of our limited study of the re-introduction of DCPs into specific areas from which all had been removed indicate that pots were relocated from the areas of their original deployment and loss. In all 4 of the cells where annual recruitment was assessed, DCPs were found with a degree of fouling or with sizes of encrusting eastern oysters that implied submergence $\geq 1$ year ( 5 out of 6 DCPs), although all crab pots were removed from these areas 1 year before, indicating that relocation rather than deployment within the last year was responsible for their presence in the cleared plots. We cannot conclude that natural physical processes necessarily caused these relocations of DCPs because human intervention, such as transport and discard by trawlers, could also explain the movement of these DCPs. In contrast to this evidence of DCP mobility, $51 \%$ of the 6 DCPs retrieved showed evidence of at least partial burial by estuarine sediments, a situation that would limit their subsequent movement.

Regulations of a NCDMF crab pot clean-out program that began in 2003 require commercial crabbers to remove all pots from the water for a period of 2-3 weeks, and a crab potting moratorium occurs typically from late January to early February. During this time, NCDMF crews remove DCPs that they find in North Carolina waters. This program is quite limited in scope and targets popular crabbing areas. Derelict crab pots retrieved by NCDMF are either disposed of, if no identification is present, or returned to the owner with a fine, if the mandated identification tag remained attached to the pot. From 2003 through 2011, NCDMF removed 21,338 DCPs from coastal waters in North Carolina ( $\left.\mathrm{NCDMF}^{12}\right)$.

In one heavily fished waterbody, few DCPs were found, possibly because fishermen were regularly removing derelict gear. Only 4 DCPs were found in the 9 cells surveyed in Jarrett Bay, within Core Sound, which has historically experienced substantial fishing and crabbing effort (Avissar, 2006; Cahoon and Hart ${ }^{13}$; Hooper $^{14}$; and Purifoy ${ }^{15}$ ). Part of this bay was open to

12NCDMF. 2011. Unpub. data. Marine Patrol, Div. Mar. Fish., North Carolina Dep. Environ. Nat. Resour., Morehead City, NC 28557 [Records obtained 27 Jan 2011.]

${ }^{13}$ Cahoon, R., and K. Hart. 2004. Evaluating the efficiency and necessity of requiring bycatch reduction devices on pots in the peeler crab fishery: qualifying and characterizing spatial and temporal overlap of activities between diamondback terrapins (Malaclemys terrapin) and the commercial fishery for peeler blue crabs (Callinectes sapidus), $13 \mathrm{p}$. North Carolina Sea Grant Project no. 03-FEG-18. [Available from North Carolina Sea Grant, 303 College Circle, Morehead City, NC 28557.]

${ }^{14}$ Hooper, M. 2010. Personal commun. Hooper Family Seafood, Smyrna, NC 28579.

${ }^{15}$ Purifoy, J. 2010. Personal commun. Inst. Mar. Sci., Univ. North Carolina Chapel Hill, Morehead City, NC 28557. a trawl fishery in 2010, and traditional crab potting areas bordered the trawl areas. Perhaps peer pressure from other fishermen or inadvertent collection and removal by trawlers was responsible for the unexpected low number of DCPs in Jarrett Bay.

\section{Bycatch or residents?}

What motivates organisms to occupy DCPs? Of the retrieved DCPs, $41 \%$ contained bycatch, most of which was alive. A separate but relevant study (senior author, unpubl. data) in Bogue Sound, North Carolina, found that scavengers quickly take remains of organisms that die in crab pots. Dead bycatch is either consumed or becomes so fragmented that it is washed out of the pot through the mesh. Only chitinous components and large bones remain for $\geq 4$ days; therefore, deaths attributable to DCPs are generally underestimated when using only the counts of bycatch found in recovered pots.

Living blue crab and Florida stone crab were found as DCP bycatch in every waterbody and every habitat type (Florida stone crab found in the cell in Newport River that was sampled for our DCP recruitment study were not part of the quantitative survey and therefore not included in the bycatch data set). Of the crabs found in DCPs, $44 \%$ of blue crab and $67 \%$ of Florida stone crab were of marketable size.

The range of the Florida stone crab has expanded northward into the region of our study. Warming surface water temperatures in North Carolina estuaries, such as the $1.4^{\circ} \mathrm{C}$ increase in the daily mean surface temperatures in Bogue Sound from 1985 to 2005 (Micheli et al., 2008), have probably facilitated the poleward expansion of populations of Florida stone crab. Populations of Florida stone crab have become well established as far north as Pamlico Sound (just north of our study area), where salinities are higher than 15, at population densities similar to densities observed for the Florida Panhandle (Rindone and Eggleston, 2011). Habitat changes may have also contributed to the increase in Florida stone crab abundance in our study area. We found more Florida stone crab in estuarine edge habitats compared with the abundance observed in marsh creek or adjacent ICW habitats (Fig. 4), a pattern that may be related to the presence of abundant rock revetments along shorelines that abut estuarine edges. Hard rock and crevice substrate is a favorable habitat for Florida stone crab and growing use of rocks to stabilize estuarine shorelines may have increased abundance of Florida stone crab in such areas (Wong et al., 2010). The degree to which Florida stone crab use DCPs and, perhaps, other structural marine debris as refuge habitat is unclear.

Some blue crab and Florida stone crab may escape from DCPs; however, as long as they are trapped they are not available to the fishery. Nonetheless, increases in abundance of Florida stone crab indicate a potential for commercial and recreational fisheries of Florida stone crab in North Carolina. Although not historically developed as a commercial fishery in North Carolina, 
landings of Florida stone crab are highly valued in Florida and prized along the U.S. Gulf Coast $\left(\mathrm{NCDMF}^{9}\right)$.

Species of concern, such as the diamondback terrapin and several coastal birds and mammals, are perhaps the most serious captures among DCP bycatch (Bishop, 1983). The results of this study and others (Bishop, 1983; Havens et al., 2011) indicate that crab pots that become derelict near marshes, essential terrapin habitat, are likely to attract terrapins and often result in their drowning. All 5 diamondback terrapins found in this study were associated with marsh habitat: 1 terrapin in a DCP in a marsh creek of the Cape Fear River and 4 juvenile terrapins in a DCP in Topsail Sound, where the ICW traverses marsh habitat. All 5 diamondback terrapin were dead yet sufficiently intact for clear identification. Hart and Crowder (2011) found that all terrapin captures in Jarrett Bay occurred between April and mid-May in baited hard-shell and peeler crab pots located $<321 \mathrm{~m}$ from the estuarine shore.

If they are improperly stored when not in use, crab pots can become a threat to wildlife. In Core Sound, 115 crab pots were tagged and properly outfitted for crabbing, stacked, and stored neatly on the marsh adjacent to the area where they were likely to be deployed. We found the remnants of bycatch organisms that included blue crab, portly spider crab, whelks or hermit crabs, and juvenile birds (skulls) in the area of dead marsh vegetation adjacent to the stacked pots and presumably where pots had been stacked previously. Large numbers of crab pots were also stacked along marsh edges at locations within Topsail Sound. Neither the stacked crab pots found on marshes nor their contents were included in the results of this study.

Derelict crab pots can provide structural habitat for organisms, initially supporting a fouling community, which subsequently provides forage and refuge habitat for other organisms. Organisms, such as Florida stone crab and mud crabs, may have chosen to reside in the DCPs that were recovered, and others, such as bivalves, algae, and tunicates, may have dispersed as propagules and then have settled on the pot surfaces. Many of the organisms that could freely pass through the pot mesh obviously elected to be part of the DCP living community and were probably subsidized energetically by organisms that became entrapped and died in pots. Eastern oysters had recruited to $17 \%$ of the retrieved DCPs and therefore specific environmental conditions and pot features may have facilitated bivalve recruitment. Perhaps DCPs made incapable of retaining bycatch could be left in the estuary to support structural habitats such as oyster reefs (Fodrie ${ }^{16}$ ).

\section{Future management considerations}

Various management actions have been used to reduce the bycatch in DCPs: 1) reduction of the numbers of DCPs (e.g., as per NCDMF ${ }^{9}$ ); 2) promotion of the use of

${ }^{16}$ Fodrie, J. F. 2010. Personal commun. Inst. Mar. Sci., Univ. North Carolina Chapel Hill, Morehead City, NC 28557. pots with panels that allow bycatch species and legally undersize blue crab to escape; and 3) promotion of the use of pots with replaceable biodegradable materials that will not remain intact for long after a pot becomes derelict. The results of our study may help to evaluate the potential effectiveness of these actions and guide strategic planning to improve fishery yields and reduce wildlife mortality attributable to DCPs. For example, our project showed that substantial numbers of DCPs were in the water despite the seasonal crab pot cleanout program of the NCDMF. That program is limited in its effectiveness by the low numbers of marine patrol staff available to participate. The clean-out program could yield a greater positive effect if other groups or individuals were allowed to remove crab pots during the crabbing moratorium period, with a requirement that they report their findings to NCDMF.

Commercial and recreational crab pots in North Carolina are distinguishable only by the color of their float; therefore, when the float is no longer attached, it is almost impossible to determine whether a DCP came from the recreational or commercial fishery. Through establishing separate recruitment study sites in areas known to be used exclusively by each fishery, the rate at which pots become derelict could be determined from the activities of each fishery. This information could help fishery managers better allocate between the fisheries incentives used for reducing crab pot loss or abandonment and resources used for DCP retrieval.

Our observations of bycatch associated with stacked crab pots on the marsh revealed that terrestrial species may also be killed as bycatch associated with the blue crab fishery. In addition, strong storms may transport these stored pots into the estuary and turn a crabber's lost investment into DCPs that ghost fish and kill fishes, crabs, terrapin, and other wildlife. Mandatory rules for permit holders that specify proper storage of crab pots might reduce the effect of stored crab pots on fishery species and other wildlife.

The geographic area of this study was limited by logistic and budgetary constraints to selected waterbodies in North Carolina, within the Central and Southern Districts of the NCDMF. Because Albemarle Sound, which is within the Northern District, produced an average of $52 \%$ of the blue crab landings in North Carolina from 2006 to $2008\left(\mathrm{NCDMF}^{7}\right)$ and was not included in our study, a similarly designed study conducted in the Northern District, especially in Albemarle Sound, would likely expand the knowledge of DCP density in the waters of North Carolina.

\section{Acknowledgments}

This study was funded in part by the NOAA Marine Debris Program, with thanks to H. Bamford, S. Morison, and C. Arthur. Specific thanks to D. Lee of The Tortoise Reserve for input on study protocols. We thank C. Rivero for providing essential GIS support for our sampling plan. We thank J. Purifoy for sharing his 
invaluable skills and expertise on the water. We also thank W. Golder, N. Loft, A. Mangiameli, R. Nelson, C. H. Peterson, R. Sicheneder, M.-K. Spillane, P. Shrestha, J. Vicente, C. Wood, R. Wood, and A. Zasadny for their contributions.

\section{Literature cited}

Avissar, N.

2006. Sea turtle damage and bycatch in North Carolina's blue crab fishery. M.S. thesis, 65 p. Nicholas School of the Environment and Earth Sciences, Duke Univ., Durham, NC. [Available at website.]

Bishop, J. M.

1983. Incidental capture of Diamondback Terrapin by crab pots. Estuaries 6:426-430. Article

Gosner, K. L.

1971. Guide to identification of marine and estuarine invertebrates, 693 p. Wiley-Interscience, John Wiley and Sons, New York.

Grosse, A. M., D. J. Van Dijk, K. L. Holcomb, and J. C. Maerz. 2009. Diamondback terrapin mortality in crab pots in a Georgia tidal marsh. Chelonian Conserv. Biol. 80:98-100.

Guillory, V.

1993. Ghost fishing in blue crab traps. N. Am. J. Fish. Manage. 13:459-466. Article

Hart, K. M., and L. B. Crowder.

2011. Mitigating by-catch of diamondback terrapins in crab pots. . Wildl. Manage. 75:264-272. Article

Havens, K. J., D. M. Bilkovic, D. Stanhope, K. Angstadt, and

C. Hershner.

2008. The effects of derelict blue crab traps on marine organisms in the Lower York River, Virginia. N. Am. J. Fish. Manage. 28:1194-1200. Article

Havens, K., D. M. Bilkovic, D. Stanhope, and K. Angstadt.

2011. Fishery failure, unemployed commercial fishers, and lost blue crab pots: an unexpected success story. Environ. Sci. Policy. 14:445-450. Article

Micheli, F., M. J. Bishop, C. H. Peterson, and J. Rivera. 2008. Alteration of seagrass species composition and function over two decades. Ecol. Monogr. 78:225-244. Article

Morison. S. E., and P. M. Murphy (eds.).

2009. Proceedings of the NOAA Submerged Derelict Trap Detection Methods Workshop; Silver Spring, MD, 2-4 June. NOAA Tech. Memo. NOS-OR\&R-32, 36 p. [Available at website.]

Morris, A. S., S. M. Wilson, E. F. Dever, and R. M. Chambers.

2011. A test of bycatch reduction devices on commercial crab pots in a tidal marsh creek in Virginia. Estuar. and Coasts 34:386-390.
NMFS (National Marine Fisheries Service).

2007. Fisheries of the United States 2006. Current Fishery Statistics No. 2006, 104 p. Natl. Mar. Fish. Serv., NOAA, Silver Spring, MD. [Available at website.]

2008. Fisheries of the United States 2007. Current Fishery Statistics No. 2007, 103 p. Natl. Mar. Fish. Serv., NOAA, Silver Spring, MD. [Available at website.]

2009. Fisheries of the United States 2008. Current Fishery Statistics No. 2008, 103 p. Natl. Mar. Fish. Serv., NOAA, Silver Spring, MD. [Available at website.]

2010. Fisheries of the United States 2009. Current Fishery Statistics No. 2009, 103 p. Natl. Mar. Fish. Serv., NOAA, Silver Spring, MD. [Available at website.]

2011. Fisheries of the United States 2010. Current Fishery Statistics No. 2010, 103 p. Natl. Mar. Fish. Serv., NOAA, Silver Spring, MD. [Available at website.]

2012. Fisheries of the United States 2011. Current Fishery Statistics No. 2011, 124 p. Natl. Mar. Fish. Serv., NOAA, Silver Spring, MD. [Available at website.]

2013. Fisheries of the United States 2012. Current Fishery Statistics No. 2012, 124 p. Natl. Mar. Fish. Serv., NOAA, Silver Spring, MD. [Available at website.]

2014. Fisheries of the United States 2013. Current Fishery Statistics No. 2013, 129 p. Natl. Mar. Fish. Serv., NOAA, Silver Spring, MD. [Available at website.]

Rindone, R. R., and D. B. Eggleston.

2011. Predator-prey dynamics between recently established stone crabs (Menippe spp.) and oyster prey (Crassostrea virginica). J. Exp. Mar. Biol. Ecol. 407:216-225. Article

Robins, C. R., G. C. Ray, and J. Douglass.

1986. A field guide to Atlantic Coast fishes of North America, 354 p. Houghton Mifflin, Boston, MA.

Roosenburg, W. M., W. Cresko, M. Modesitte, and M. B. Robbins.

1997. Diamondback terrapin (Malaclemys terrapin) mortality in crab pots. Conserv. Biol. 11:1166-1172. Article

Roosenburg, W. M., K. L. Haley, and S. McGuire.

1999. Habitat selection and movements of diamondback terrapins, Malaclemys terrapin, in a Maryland estuary. Chelonian Conserv. Biol. 3:425-429.

Ruppert, E., and R. Fox.

1988. Seashore animals of the Southeast: a guide to common shallow-water invertebrates of the southeastern Atlantic coast, 429 p. Univ. South Carolina Press, Columbia, SC.

Wong, M. C., C. H. Peterson, and J. Kay.

2010. Prey size selection and bottom type influence multiple predator effects in a crab-bivalve system. Mar. Ecol. Prog. Ser. 409:143-156. Article 